\title{
Modification of thermal and oxidative properties of biodiesel produced from vegetable oils
}

\author{
G. El Diwani; *S. El Rafie \\ Chemical Engineering and Pilot Plant Department, National Research Center, Cairo, Egypt \\ Received 9 January 2008; revised 28 January 2008; accepted 12 March 2008
}

\begin{abstract}
Trans esterification of three vegetable oils, sunflower oil, linseed oil and mixed oils as; sunflowersoyabean and olein were carried out using methanol, and potasium hydroxide as catalyst. The methyl esters of the corresponding oils were separated from the crude glycerol and characterized by physical-chemical methods to evaluate their thermal properties. This methods are determination of densities, cloud points, pour points, flash points, kinematic viscosities, hydrogen/carbon ratios, sulfur contents, ash contents and triglycerides. The physico-chemical characteristic of biodiesel treated with ozone showed improvement of pour point and flash point indicating higher degree of safety for fuel. Methyl esters mixed with their corresponding ozonated oil were subjected to comparison and evaluation for their thermal properties by the thermo gravimetric analysis differential thermal analysis from which the calculated heat of enthalpy and comparison with the heat of conventional diesel. The results showed that the oxygen content of biodiesel samples treated with ozone increased weight $\%$ and resulted in more extensive chemical reaction, promoted combustion characteristics and less carbon residue was produced. Gas chromatography appeared more suitable to address the problem of determining/verifying biodiesel methyl ester and showed that methyl ester content was impurity free. Ultra violet-detection was used for rapid quantization of triglycerols. From the analyses performed biodiesel treated with ozone modified the thermal and oxidative stability shown by the high combustion efficiency indicated by the high heat of enthalpy and reducing the emission of particulate matter.
\end{abstract}

Key words: Renewable fuel, properties, thermal analysis, oxidative stability, ozonation

\section{INTRODUCTION}

Biodiesel is an alternative fuel for diesel engines that is produced by chemically reacting a vegetable oil with an alcohol such as methanol. Commonly used alcohols include methanol, ethanol, propanol and butanol. However, the yield of biodiesel is independent of the type of the alcohol used and the selection of one of these depends on cost and performance. Methanol is performed over others due to its low cost (Ramadhas et al., 2005). The reaction requires a catalyst, usually a strong base such as potassium hydroxide, and produces new chemical compounds called methyl esters. It is these esters that have come to be known as biodiesel (Jon, 2005). The interest in the use of renewable fuel started with the direct use of vegetable oils as a substitute for diesel. However, their direct use in compression ignition engines was restricted due to high viscosity which resulted in poor fuel atomization, incomplete combustion and carbon

*Corresponding Author Email: shelrafie0000yahoo.com Tel.: +2 333 71362; Fax: +2 33370931 deposition on the injector and the valve seats causing serious engine fouling (Ramadhas et al., 2005). To overcome these constraints, the processes like pyrolysis, micro-emulsification, transesterifiation, etc. were especially developed. Transesterification is a chemical reaction between triglyceride and alcohol in the presence of catalyst. It consists of a sequence of three consecutive reversible reactions where triglycerides are converted to diglycerides, as well as they are converted to monoglycerides followed by the conversion of monoglycerides to glycerol. In each step an ester is produced from one molecule of triglyceride (Sharma and Singh, 2007).

Because its primary feed stock is a vegetable oil, biodiesel is generally considered to be renewable. Various oils have been in use in different countries as raw materials for biodiesel production owing to its availability. Other edible and non-edible oils, animal fats, algae and waste cooking oils have also been investigated by researchers for the development of 
biodiesel (Wang et al., 2007; Canakci, 2007; Leung and Guo, 2006; Granados et al., 2007; Zhang et al., 2003; Tashtoush et al., 2004). The major constraint of direct application of waste frying oil lies in its higher amount of free fatty acid (FFA). Researchers have advocated the use of rendered animals fats and restaurant waste oils as biodiesel feed stocks (Canac and Gerpan, 2003; Engelman et al., 1978; Langue et al., 1988; Cigizglu et al., 1997; Ozbay et al., 2008). Unsaturated compounds have better low temperature properties but fail in oxidation stability. The waste oil product can be of advantage over the neat vegetable oils as they have a higher proportion of saturated fatty acids (Sarin et al., 2007). Although biodiesel cannot entirely replace petroleum based diesel fuel, there are at least five reasons that justify its development. It provides a market for excess production of vegetable oils, it decrease the dependence on imported petroleum, it does not contribute to global warning due to its closed carbon cycle, the exhaust emissions of carbon monoxide, unburned hydrocarbons, and particulate emissions from biodiesel are lower than with regular diesel fuel, when added to regular diesel fuel in an amount up to $20 \%$ it can convert fuel into an acceptable fuel (Ayhau, 2001). Transesterification reaction is the most commonly applied technique to produce biodiesel. Vegetable oil, which is a composition of triglycerides reacts with alcohol, with the help of a catalyst to form alkyl esters and glycerin as in the following reaction:

Triglyceride + methanol $\longrightarrow$ mixture of fatty esters + glycerin

The manufacturing process of biodiesel can be divided into three systems based on the type of catalyst used in the transesterification reaction, which are strong alkali, strong acid, and enzyme. The process of transesterification by a strong alkali catalyst is required in reaction and it is widely applied in commercialized biodiesel production (Knothe, 2001). This study proposes experimental evaluation of biodisel properties prepared by transesterification using strong alkali catalyst $\mathrm{KOH}$ for esterifying three types of refined vegetable oils (VOs) sunflower, Linseed oil and mixed oil (sunflower, soyabean oil and olien oil)and same biodiesel mixed with ozonated corresponding oil (Nestor et al., 2006).The study depends on that, the properties of the various individual fatty esters that comprise biodiesel determination the overall fuel properties of the biodiesel fuel (Refaat et.al., 2008;
Martin, 1996). Actually, thermo-analytical methods as differential thermal analysis (DTA) and thermogravimetric analysis (TGA) have received considerable attention (Jayadas and Prabhakaran, 2006). These methods are advantageous in relation to the conventional ones because they present a higher precision and sensitivity as well as use small amount of sample and the results is obtained faster. Though TGA and DTA are extensively used for analyzing the thermal and oxidative stabilities of edible oils. The more resistant biodiesel to oxidation, less is the tendency it has to form deposits, sludge and corrosive by products in grease, engine oil applications (Buzas and Hollo, 2005). It is also more resistant to undesirable viscosity increase during use. Many earlier studies have studied reaction of ozone on cell constituents. These macromolecules have special feature is that their specific structural conformations are dictated by lowenergy bonds. A study of ozone effects on cell constituents is very complicated. Moreover the large number of reactive sites in cell constituents can induce different types of direct ozone reaction mechanism as well as radical reactions. Simple lipids are glycerol and fatty acid (Saturated and unsaturated) esters reacts with ozone with the main cell-forming components, the rate constants have almost all been obtained in a batch reactor by mixing a solution of the component under study with a solution of ozone. Some studies on the consumption of ozone (stoichiometric) or ozonation products were performed in semibatch or bubblecollumn-type units (Burno et al., 1991). Saturated fatty acid, the main constituent of lipids, react only slightly with ozone, as can be seen from the few kinetic constants obtained by (Hoing and Bader, 1983b). However, their reactivity increases when there are several ethylenic bonds in the carbonated chain. When this occurs, the main ozonation products are aldehyde, acids and hydrogen peroxides, demonstrating a probable ozone attack by 1-3 dipolar cyclo addition on the double bond. A common example is that of oleic acid ozonation, resulting in the formation of hydrogen peroxide (Spanggord and Cing, 1978). One naturally occurring fatty acid, 9-hexadecenoic acid, was found to be completely destroyed by ozonation in the Los Angeles Aqueduct water. Because it contains a double bond, (Glaze, 1988) suspectedly it was a precursor for some of the aldehydes and carboxylic acids formed. In laboratory studies by (Glaze, 1988), spiked solutions of this fatty acid were ozonated and yielded heptanol 
and heptanoic acid, presumably through the formation of an intermediate as part of the Griegee mechanism (Bailey, 1978). While heptanal and heptanoic acid were the result of the reaction on one side of the double bond, 9-oxononanoic acid and nonanedioic acid were the result of the other side. In laboratory studies, (Glaze, 1988) ozonated raw water at varying doses. The naturally occurring $\mathrm{C}_{9}$ through $\mathrm{C}_{11}$ aldehydes all increased in concentration up to a given dose (near 1 $\mathrm{mg} / \mathrm{L}$ ), after which their concentrations fell off. This is consistent with the trend in (Schaleekanp, 1978). Lower ozone doses brought about lower levels of heptanal, presumably through conversion to heptnowic acid. These types of results have been substantiated in model systems using pure solutions of unsaturated fatty acids. This study aimed to test and modifie thermal properties of three biodiesel, by treating them with corresponding ozonated oil $1 \%$ (weight) and their thermal properties where compared to net biodiesel produced from normal transesterification. This was based on enthalpy rate for biodiesel with temperature and calculating its heat capacity. This work have been performed in the National Research Center, Chemical Engineering and Pilot Plant Department, Cairo, Egypt, through the second progress report March, 2007. U.S.Egypt Science and Technology Program.

\section{MATERIALS AND METHODS}

VOs, sunflower, linseed oil and the mixed oils (mixture of soya bean, sunflower and olein). Methyl alcohol, ethyl alcohol, bromine, chloroform, acetic acid and distilled water. Potassium hydroxide, sodium hydroxide, sodium sulphate, sodium thiosulpfate, potassium iodide, soluble starch and Hanns reagent. All chemicals used are of analytical grade. The experimental work was performed in National Research Center, Department of Chemical Engineering and Pilot Plant in 2007. Glass reactor equipped with magnetic stirrer for efficient mixing and a reflux condenser to condense back escaping methanol. Separating funnel to separate produced ester from glycerol. Instruments for products evaluation: Viscometer, Brook FTELD model DV-II. Different glasswares needed to titremetric technique for acid value, Iodine value, peroxide value, saponification value and peroxide value. Gas chromatography Auto system XL, PerkinElmer type. UV/VIS spectrophotometer P4, using kits randox for triglycerides (Gerhard and Kevin, 2001). Normal transesterification reaction: Potassium methoxide solution was prepared freshly by mixing a predetermined amount of methanol ( $20 \%$ by weight of oil) with $\mathrm{KOH}(1 \%$ by weight of oil) in a container. The reaction was carried out for $2 \mathrm{~h}$. under reflux at 60-70 ${ }^{\circ} \mathrm{C}$. Stirring was started with the reaction, at the moment of adding potassium methoxide solution, till homogenous phase appear and then stirring was stopped. The reaction mixture was carefully transferred to separating funnel and allowed to stand over night. The lower layer (glycerol, methanol and most of the catalyst) was drained out. The upper layer (methyl ester, some methanol and trace of the catalyst) was then cleaned by washing with warm $\left(50^{\circ} \mathrm{C}\right)$ distilled water. The methyl ester was then dried with anhydrous $\mathrm{Na}_{2} \mathrm{SO}_{4}$.

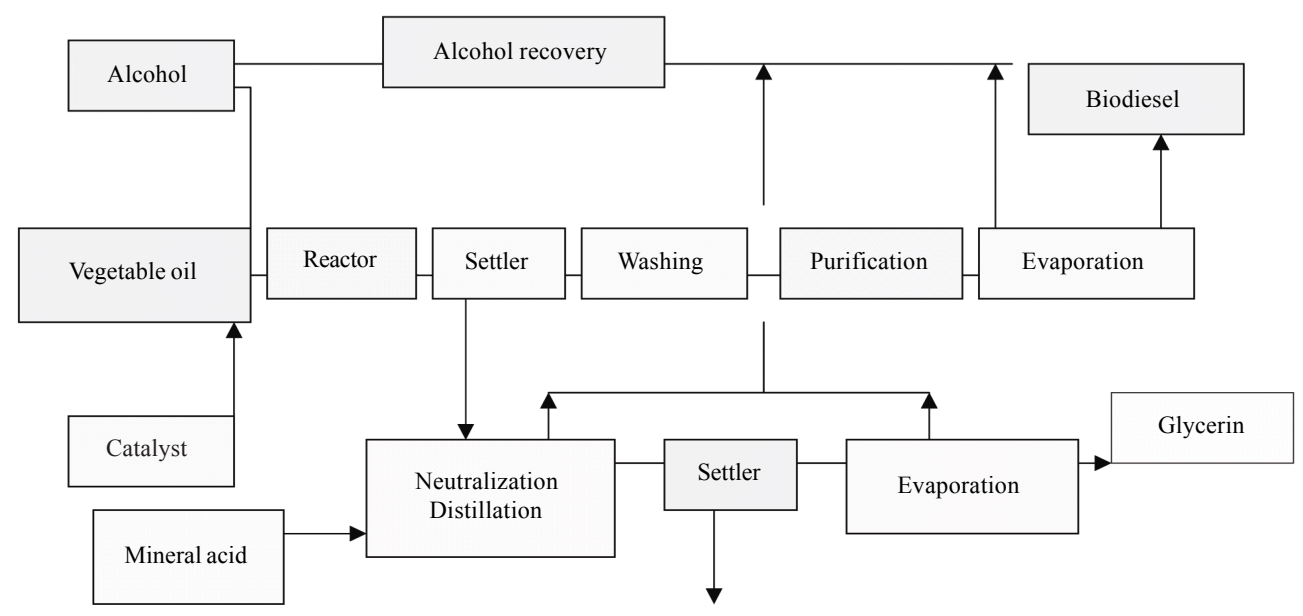

Fig. 1: Flow chart of the process of normal esterification to create biodiesel fuel 
Oils under test were ozonated by bubling ozone gas at a dose of $40 \mathrm{~g} \mathrm{O}_{3} / \mathrm{m}^{3}$ at a rate of $0.5 \mathrm{~L} / \mathrm{min}$. After complete ozonation, nitrogen gas is purged into the ozonated oil to get rid of the un reacted ozone. Ozonated vegetable oils were added ( $1 \%$ by weight $)$ and stirred thoroughly for well mixing with biodiesel at $40^{\circ} \mathrm{C}$ using a water bath.

Thermogravimetry was accomplished using TA instrument model Shimadzu TGA unit $50 \mathrm{H}$. The TGA cell was swept with nitrogen at flow of air $(20 \mathrm{~mL} / \mathrm{min})$ as purge gas was used in order to burn out the fuel during analysis to estimate their heat of combustion. The heating rate of $10 \mathrm{C} / \mathrm{min}$. from $0-500^{\circ} \mathrm{C}$ was used during degradation runs. Platinum samples pans were used for samples size $11.81 \mathrm{mg}, 5.148 \mathrm{mg}$ and $13.35 \mathrm{mg}$ for sunflower fuel, mixed oil fuel and linseed fuel respectively. Using standard procedures as listed in Table 3, physical and chemical properties such as density, heat of combustion, cloud and pour point, flash point, acid value and iodine value were determined. The gas chromatography Shimadzu was used to determine the esters fatty acid. Calorimeter DSC 2010 with a TA 2100 PC- based controller was used for triglycerides determination.

\section{RESULTS AND DISCUSSION}

Gas chromatography chromatograms shows that biodiesel samples produced that is impurity free. The most common fatty acid was linoleic, at pproximately $159.1,106.65,178.3 \mathrm{mg} / \mathrm{mL}$ of the total fatty acid in the esters (FBD), (LBD), (MBD) and for esters treated with ozone results were $186.65,124.15$ and $184 \mathrm{mg} / \mathrm{mL}$ $\left(\mathrm{FBDO}_{3}\right),\left(\mathrm{LBDO}_{3}\right)$ and $\left(\mathrm{MBDO}_{3}\right)$ respectively. Oleic acid was the next common fatty acid in the esters. The third most common fatty acid methyl ester was linolenic acid.
The variation of weight proportions of saturated and unsaturated fatty acids of the samples sunflower biodiesel (FBD), Linseed bidiesel (LBD), mixed oil biodiesel (MBD), ozonated $\left(\mathrm{FBDO}_{3}\right),\left(\mathrm{LBDO}_{3}\right)$ and $\left(\mathrm{MBDO}_{3}\right)$ were studied (Table1). Samples treated with ozone were found to have larger weight proportion of saturated carbon bonds and lower unsaturated carbon bonds. The weight proportion of saturated carbon bonds were $14.35,22.5$ and $31.75 \mathrm{mg} / \mathrm{mL}$ for samples (FBD), (LBD), (MBD) and 21, 25 and $32.05 \mathrm{mg} / \mathrm{mL}$ for ozonated samples $\left(\mathrm{FBDO}_{3}\right),\left(\mathrm{LBDO}_{3}\right)$ and $\left(\mathrm{MBDO}_{3}\right)$ respectively. This implied that the saturated carbon of the biodiesel were increased by $31.66,10$ and 0.9 wt $\%$ when treated with ozonated corresponding oil Table 3.

The fatty acid of $18: 1$ carbon bonds were significantly increased from $67.75-85.2 \mathrm{mg} / \mathrm{mL}$ i.e. $20.48 \%$ in sample $\left(\mathrm{LBDO}_{3}\right)$. In contrast, the weight proportion of fatty acid of 18:1 carbon bonds were slightly decreased down to 8.12 and 13.30 in (FBD) and (MBD) samples. The weight proportion of fatty acid 18:2 carbon bonds showed an increase up to $14 \%$ for (FBD) and (LBD) samples, while a slight increase of 3 wt $\%$ appeared for $\left(\mathrm{MBDO}_{3}\right)$ sample. The $\left(\mathrm{FBDO}_{3}\right)$ treated with ozone showed increase in weight proportion of the saturated carbon bonds. The number of unsaturated double carbon bonds of biodiesel was reduced causing reduction of the combined relative oxidation rate.

The physico-chemical characterization such as: densities, cloud points, pour points, flash point, kinematic viscosity, $\mathrm{H} / \mathrm{C}$ ratio, sulfur content and triglycerides and ash content are given in Table 2 . The densities of methyl esters were in the range of 886,847 and $828 \mathrm{Kg} / \mathrm{m}^{3}$ and decreased in the order of

Table 1: Fatty acid constitution of considered vegetable oils

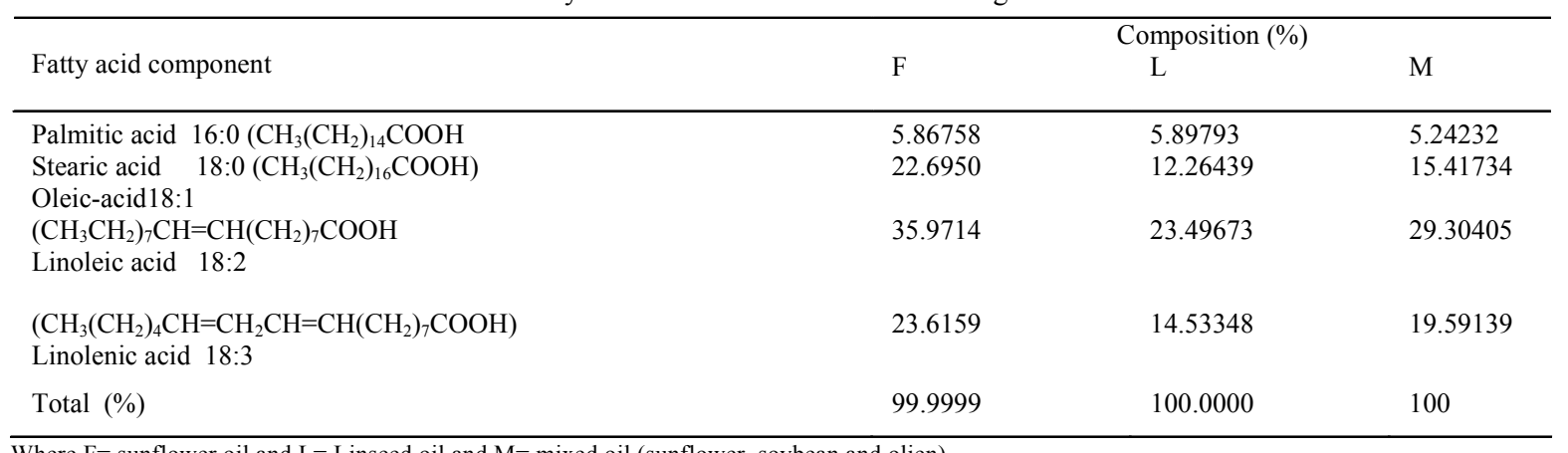

Where $\mathrm{F}=$ sunflower oil and $\mathrm{L}=$ Linseed oil and $\mathrm{M}=$ mixed oil (sunflower, soybean and olien) 
Table 2: Specification of biodiesel produced in this study

\begin{tabular}{|c|c|c|c|c|c|}
\hline \multirow{2}{*}{$\begin{array}{l}\text { Biodiesel properties } \\
\text { USA National Standards }\end{array}$} & & \multicolumn{3}{|c|}{ Biodiesel } & \multirow{2}{*}{$\begin{array}{l}\text { Procedure } \\
\text { ASTM method }\end{array}$} \\
\hline & & FBD & LBD & MBD & \\
\hline Specific gravity & 0.838 & 0.847 & 0.886 & 0.828 & 1298 \\
\hline Cloud-point, ${ }^{\circ} \mathrm{C}$ & NA & +3 & 0 & 0 & 2500 \\
\hline Pour point, ${ }^{\circ} \mathrm{C}$ & - & 0 & -6 & -3 & 97 \\
\hline Flash point, ${ }^{\circ} \mathrm{C}$ & $>100$ & 172 & 175 & 173 & 93 \\
\hline Kinematic-viscosity & & 2.203 & 2.411 & 2.216 & 445 \\
\hline Sulfur & $<0.05$ & 0.52 & 0.33 & 0.30 & $\%$ mass \\
\hline Triglycerides & - & 21.42 & 9.544 & 11.69 & $\%$ mass \\
\hline Ash content & - & 0 & 7.0 & 0.43 & $\%$ mass \\
\hline Acid value & - & 0 & 0 & 0 & 664 \\
\hline Iodine value & $<120$ & 329. & 293.9 & 340.8 & 5291 \\
\hline $\mathrm{H} / \mathrm{C}$ ratio & & 0.147 & 0.047 & 0.036 & $\%$ mass \\
\hline Methanol content & $<0.2$ & 0 & 0 & 0 & $\mathrm{GC}$ \\
\hline
\end{tabular}

Table 3: Weight increase $\%$ of methyl ester after ozonation

\begin{tabular}{|c|c|c|c|c|c|}
\hline \multirow{3}{*}{$\begin{array}{l}\text { Biodiesel } \\
\mathrm{C} \mathrm{N0}\end{array}$} & \multirow{2}{*}{\multicolumn{2}{|c|}{ Saturated composition }} & \multicolumn{3}{|c|}{ Unsaturated composition } \\
\hline & & & \multirow{2}{*}{$\frac{\text { Mono-unsaturated }}{\mathrm{C} 18: 1}$} & \multicolumn{2}{|c|}{ Poly unsaturated } \\
\hline & C16: & C18:0 & & C18:2 & C18:3 \\
\hline C18:0LBDO & 31.66 & 0.00333 & 8.124 & 14.76 & 49.068 \\
\hline \multirow[t]{2}{*}{ MBDO } & 10 & 57.4 & 20.48 & 14.09 & 10.93 \\
\hline & 0.9 & 43.06 & 13.303 & 3.097 & 24.41 \\
\hline
\end{tabular}

LBD $>$ FBD $>$ MBD. The densities of No. 1 canadian winter (LSD - 43 Diesel light) and of the N0. 2 summer diesel fuel $(\mathrm{C}-5 \mathrm{Seasonal}$ diesel) were 820 and $860 \mathrm{Kg} /$ $\mathrm{m}^{3}$ respectively. The cloud point Table 2 methyl esters ranged from 0 to $+3{ }^{\circ} \mathrm{C} \mathrm{LBD}$ and MBD had the lower cloud point and FBD had the highest. The pour point of methyl ester ranged from -6 to $0^{\circ} \mathrm{C}$. The LBD had the lowest pour point $\left(-6^{\circ} \mathrm{C}\right)$ and $\mathrm{FBD}$ showed the highest $\left(0^{\circ} \mathrm{C}\right)$. MBD had in between pour point of $-3{ }^{\circ} \mathrm{C}$ and $-0{ }^{\circ} \mathrm{C}$, respectively. The $\mathrm{BD}$ treated with corresponding ozonated oil showed a decrease in pour point less to $\left(-3^{\circ} \mathrm{C}\right)$ for $\mathrm{LBDO}_{3}$ and showed no change for $\mathrm{FBDO}_{3}$, while showed an increase up to $\left(0^{\circ} \mathrm{C}\right)$ for $\mathrm{MBDO}_{3}$. The flash point of three biodiesel in Table 2, the LBD has a slightly higher flash point among these three fuel and is nearly triplet that of the ASTM No. $2 \mathrm{D}$ diesel $\left(65^{\circ} \mathrm{C}\right)$. A higher flash point indicates higher degree of safety for the storage, transportation and usage of liquid fuel. Whereas BD mixed with corresponding ozonated oil showed no change in $\mathrm{FBDO}_{3}$ flash point. The $\mathrm{LBDO}_{3}$ showed one degree decrease of its flash point and only $\mathrm{MBDO}_{3}$ showed two degree increase when treated with sunflower ozonated oil hence improved the flash point.

The kinematic viscosities of ASTM No. 2D diesel, samples FBD, MBD and LBD are, 2.203, 2.411 and 2.216 CST, respectively as shown in Table 2 . The specification of Kinematic viscosity is in this range of 1.9-6.0 CST in the ASTM D6751 biodiesel standard (Gerhard et al., 2005). The kinematic viscosities of the biodiesel produced in this study are in the range of both the ASTM D6751 and EN 14214 biodiesel standards, although the kinematic viscosities of these two biodiesel are slightly higher than that of the ASTM No. 2D diesel fuel.

The sulfur content in biodiesel generally is less than 15 ppm sulfur ASTM D 5433 test. Sulfur content in Table 2 shows very low mass $\%$ for $\mathrm{MBD}<\mathrm{LBD}<\mathrm{FBD}$ of sequence $0.03 \%, 0.033 \%$ and $0.052 \%$ respectively. The ash content after burning the methyl ester FBD is shown to have zero value. MBD showed undesirable $0.43 \%$ of ash content and LBD contains highest ash content of $7.05 \%$ Table 2 . The ash content is controlled to ensure that all the catalysts used in the 
transesterification process are removed. Presence of ash can cause filter plugging and or injector deposits. Soluble metallic soap, soap un-removed catalysts and other solids are possible sources of sulfated ash in the fuel. Most of the biodiesel standards, except Austrian and ASTM, specify a maximum limit of $0.08 \%$ mass for mono glycerides. Draft EU standard calls for some limits. Di-and triglycerides are also controlled in most of the standards. High levels of these glycerids can cause injector fouling, filter clogging etc. The prepared biodiesel showed $0.06,0.0535$ and $0.083 \%$ mass for FBD, LBD and MBD indicating values in the limits. The alcohol levels in the prepared biodiesel samples showed zero values using GC chromatography.

The undesirable high levels of free alcohol in biodiesel cause accelerated deterioration of natural rubber seals and gaskets. Damage to fuel pumps and injectors which have natural rubber diaphragms has been very common type of failure. Methanol is membrane-permeable and caused never damage. The $\mathrm{H} / \mathrm{C}$ ratio content showed a sequence of $0.147>0.047>$ 0.036 for produced biodiesel FBD, LBD and MBD. This indicated carbon content of 71.9, 78.77 and 75.09. Many earlier studies for thermal and oxidative stabilities have shown that a heating rate of $10{ }^{\circ} \mathrm{C} / \mathrm{min}$ yield better information about the thermal behavior (Jon, 2005) and (Marta et al., 2007), hence adapted for our studies. TGA curves show percentage weight of the sample remains constant till the decomposition of its content begins Figs. 3 and $4(a-b)$.

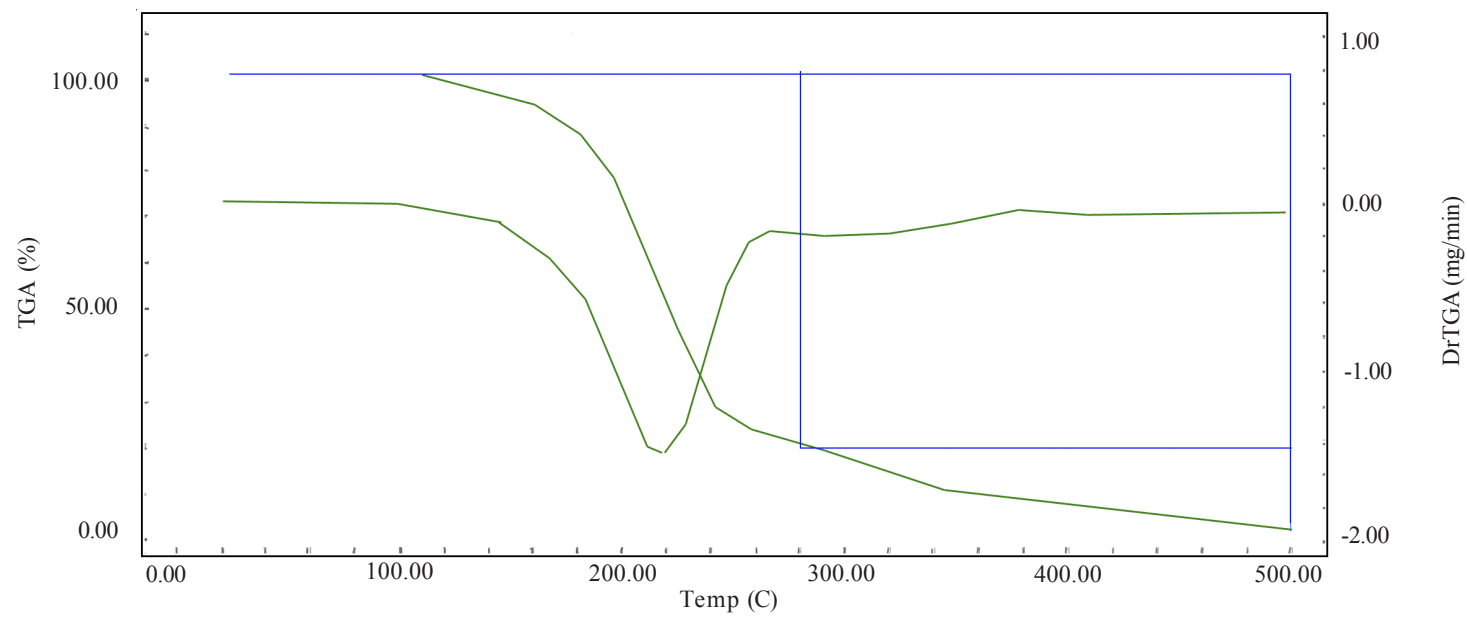

Fig. 3: TGA curve for FBD sample showing its thermal decomposition

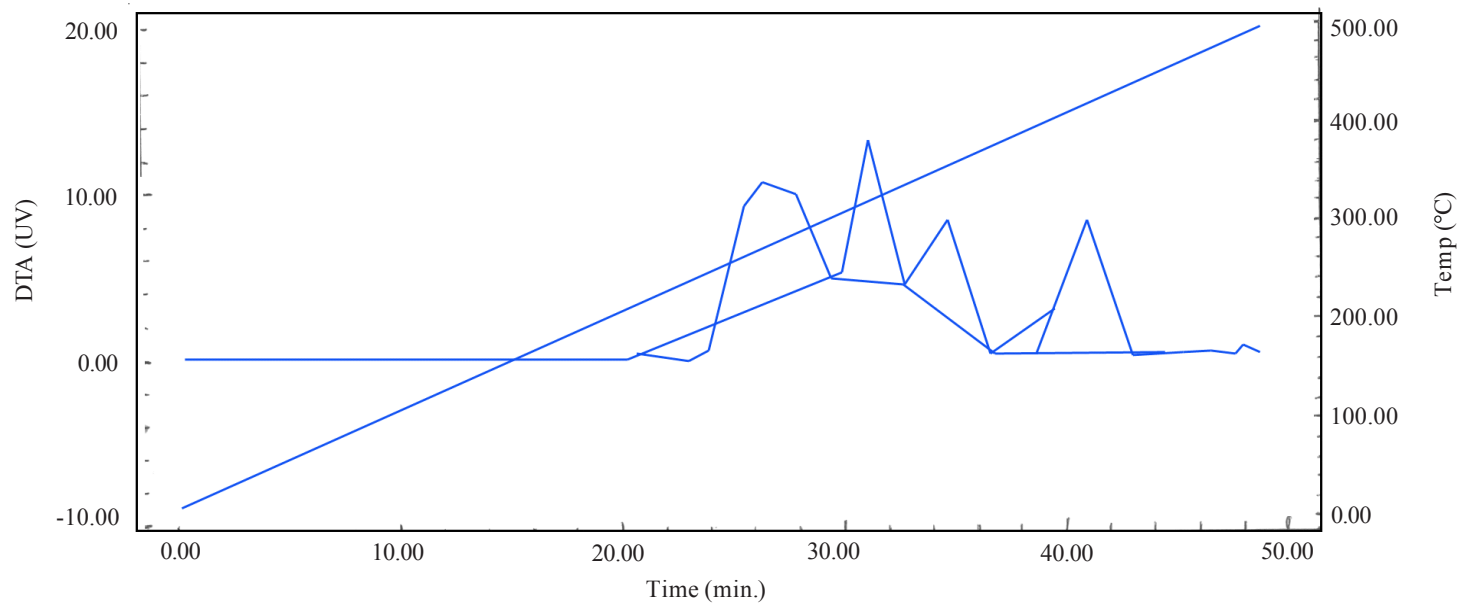

Fig. 4a: TDA curve for FBD sample showing its thermal degradation steps 


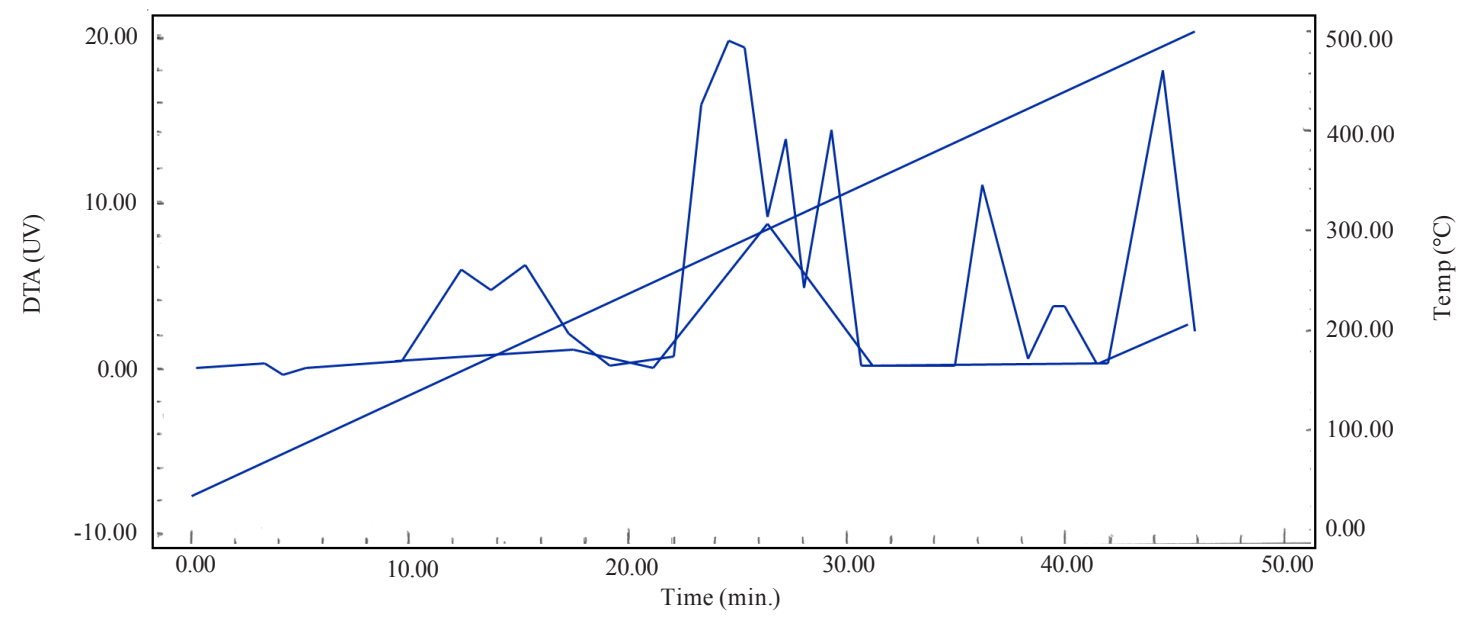

Fig. 4b: TDA curve for $\mathrm{FBDO}_{3}$ showing its improved thermal degradation steps

339.23, 344.99-374.12 and 400.15-441.59 ${ }^{\circ} \mathrm{C}$ with respective mass losses $97.75 \%, 78.97 \%$ and $18.47 \%$. The decomposition process of fuel at previous stated temperatures presented respective heat $1.30,0.776$, 0.578 and $1.28 \mathrm{~J} / \mathrm{mg}$. The process of volatilization of (FBD) biodiesel initiates and finiches in temperatures inferior to the FBD biodiesel volatilization beginning and end temperatures, coming close to volatilization of conventional diesel temperatures. Hence FBD biodiesel potential is confirmed as a fuel alternative. As well as, TG curves of biodiesel $\mathrm{FBDO}_{3}$ mixed with treated ozonated corresponding oil presented seven stages of thermal decomposition indicating more stability for improved $\left(\mathrm{FBDO}_{3}\right)$. These consecutive stages of thermal decomposition have been attributed to onset - endset temperatures $(133.67-212.53,261.66-$ 304.87, 323.32-345.08, 390.80-417.71, 425.07-452.25, 305.92-321.44 and 62.89-498.70) with respective mass losses $14.39 \%, 16.18 \%$ and $1.674 \%$ i.e. $(85.28 \%$, $79.51 \%$ and $90.94 \%$ were conserved from fuel mass losses during thermal decomposition process at temperatures presented respective heat 1.73, 2.14, 0.795, $0.999,0.3327,2.06$ and $0.298 \mathrm{~J} / \mathrm{mg}$. Comparing heat of conventional diesel $(0.1033 \mathrm{~J} / \mathrm{mg})$ and that of $\left(\mathrm{FBDO}_{3}\right)$ $(0.784 \mathrm{~J} / \mathrm{mg})$ indicated both effects of ozone on stability of oxidation and modification of thermal properties. As explained in the previous discussion the following onset temperatures of thermal degradation showed sequence of $\mathrm{FBD}>\mathrm{MBD}>\mathrm{LBD}$ while the onset temperatures of $\mathrm{BD}$ samples treated with ozonated corresponding oil showed thermal degradation with improvement for $\mathrm{LBDO}_{3}$ thermal properties in the following sequence $\mathrm{FBDO}_{3}>\mathrm{LBDO}_{3}>\mathrm{MBDO}_{3}$. This is attributed to the heat of enthalpy calculated in $\mathrm{J} / \mathrm{mg}$ sample in the sequence of $0.333,0.0405$ and 1.089 for FBD, LBD and MBD. The increase of heat showed an increasing value for samples treated with ozonated corresponding oil in the sequence of $0.784,0.198,0.1085$ and $0.3785 \mathrm{~J} / \mathrm{mg}$ respectively.

Table 5 shows also the conventional diesel heat of enthalpy equal to $0.1033 \mathrm{~J} / \mathrm{mg}$. The heat of conventional diesel shows $1 / 7$ of that produced by $\mathrm{FBDO}_{3}$ and nearly equal to that of $\mathrm{MBDO}_{3}$ and $1 / 2$ of produced heat of $\mathrm{LBDO}_{3}$. In comparison for the $\mathrm{MBDO}_{3}$ that was treated with ozonated sunflower oil $1 \%$ by wt showed an increase in heat produced over that of conventional diesel by three folds. Thus, in order to improve $\mathrm{MBDO}_{3}$, ozonated sunflower oil (1\% by wt) was added to $\mathrm{MBDO}_{3}$, this modified MBD thermal properties showing better DTA results. These modifications results in our study agreed with (Hoigne and Bader, 1983b). They introduced processes of ozonation into conventional biodiesel. They indicated that ozonation was effective for reducing molecular weight of methyl ester and extremely reduced the flash point.

The DTA curve for thermal decomposition of FBD samples in Fig. 4. shows that thermal degradation takes place in a single continuous step where as FBD samples treated with ozone showed several steps for thermal degradation $\mathrm{FBDO}_{3}>\mathrm{LBDO}_{3}>\mathrm{MBDO}_{3}$. While $\mathrm{MBDO}_{3}$ mixed with ozonated sunflower oil ( $1 \%$ by wt) instead of mixing it with the corresponding ozonated achieved. 
Thermal and oxidative properties of biodiesel fuel

Table 5: Onset temperature of thermal and oxidative degradation

\begin{tabular}{|c|c|c|c|c|c|c|c|}
\hline $\begin{array}{l}\text { Biodiesel / } \\
\text { mass mg }\end{array}$ & $\begin{array}{l}\text { Onset } \\
\text { (Temp) }\end{array}$ & $\begin{array}{l}\text { Mass loss } \\
(\%)\end{array}$ & $\begin{array}{l}\text { Heat in } \mathrm{g} \\
(\mathrm{J} / \mathrm{mg})\end{array}$ & $\begin{array}{l}\text { Biodiesel treated } \\
\text { by ozonated oil }\end{array}$ & $\begin{array}{l}\text { Onset } \\
\text { (Temp) }\end{array}$ & $\begin{array}{l}\text { Mass loss } \\
(\%)\end{array}$ & $\begin{array}{l}\text { Heat in } g \\
(\mathrm{~J} / \mathrm{mg})\end{array}$ \\
\hline \multirow[t]{7}{*}{ FBD / 11.81} & 259.09 & -97.756 & 1.30 & \multirow{9}{*}{$\begin{array}{l}\mathrm{FBDO}_{3} \\
/ 10.66\end{array}$} & 133.67 & -14.39 & 1.73 \\
\hline & 313.5 & -9.328 & 0.776 & & 261.66 & -16.18 & 2.14 \\
\hline & 344.99 & -18.476 & 0.578 & & 323.32 & -1.674 & 0.795 \\
\hline & 400.15 & & 1.28 & & 390.80 & & 0.999 \\
\hline & & & & & 425.07 & & 0.3327 \\
\hline & & & & & 305.92 & & 2.06 \\
\hline & & & & & 462.89 & & 0.29 \\
\hline \multirow[t]{2}{*}{ Total } & & & 3.934 & & & & 8.35 \\
\hline & & & $0.333 / \mathrm{mg}$ & & & & $0.784 / \mathrm{mg}$ \\
\hline \multirow[t]{6}{*}{$\begin{array}{l}\mathrm{LBD} / \\
13.35\end{array}$} & 191.05 & -97.7 & -1.30 & $\begin{array}{l}\mathrm{LBDO}_{3} \\
/ 13.27\end{array}$ & 201.96 & -30.43 & 0.3844 \\
\hline & 249.55 & & 0.760 & & 250.90 & -32.43 & 2.14 \\
\hline & & & & & 286.43 & & 0.6773 \\
\hline & & & & & 246.99 & & -0.796 \\
\hline & & & & & 311.57 & & 1.00 \\
\hline & & & -0.54 & & & & 2.637 \\
\hline Total & & & $0.04045 / \mathrm{mg}$ & & & & $0.1987 / \mathrm{mg}$ \\
\hline \multirow[t]{7}{*}{$\begin{array}{l}\mathrm{MBD} / \\
5.148\end{array}$} & 72.41 & 341.29 & -0.97 & $\begin{array}{l}\mathrm{MBDO}_{3} \\
/ 12.77\end{array}$ & 167.56 & -28.59 & 0.157 \\
\hline & 272.99 & -90.94 & -0.924 & & 221.51 & -31.85 & 0.755 \\
\hline & 341.29 & -0.842 & 1.78 & & 314.75 & -5.13 & 0.208 \\
\hline & & -16.36 & 2.20 & & 351.60 & & 0.2654 \\
\hline & & & 1.57 & & & & \\
\hline & & & 1.95 & & & & \\
\hline & & & 5.606 & & & & 1.385 \\
\hline Total & & & $1.089 / \mathrm{mg}$ & & & & $0.1085 / \mathrm{mg}$ \\
\hline \multirow[t]{4}{*}{$\begin{array}{l}\text { Conven-tional } \\
\text { diesel / } 11.52\end{array}$} & 223.00 & -98.683 & & $\begin{array}{l}\mathrm{MBDO}_{3} \\
/ 12.84\end{array}$ & 275.47 & -32.69 & 4.05 \\
\hline & & & & & 2525 & -27.52 & -1.06 \\
\hline & & & & & 336.90 & -5.133 & -1.87 \\
\hline & & & 1.19 & & & & 4.8 \\
\hline Total & & & $0.1033 / \mathrm{mg}$ & & & & $0.3785 / \mathrm{mg}$ \\
\hline
\end{tabular}

Where MBDO = ozonated with corresponding oil and MBDO = ozonated with sunflower oil

The thermal and oxidative stabilities are determined from the onset - endset temperature of decomposition under nitrogen atmosphere. To allow for the weight loss due to moisture content and high volatile components the onset temperature is determined at $2 \%$ loss of mass. The onset temperatures of the thermal as well as oxidative decomposition for the three BDF samples are shown in Table 5. TG curves of biodiesel (FBD) presented four stages of thermal decomposition, which are consecutive and have been attributed to volatilization and/or decomposition of fuel mainly of Linolenic fatty acid at temperatures of onset-endset 259.09-310.97, 313.50-modified degradation. 
The thermal decomposition of BDF samples involves the breaking down of the oxygenated hydrocarbon present in it into volatile lower molecular hydrocarbons, carbon dioxide and carbon monoxide. Though the onset temperatures are lower for $\mathrm{MBD}>\mathrm{LBD}>\mathrm{FBD}$ and there is considerable weight gain in the temperature range $0{ }^{\circ} \mathrm{C}-100{ }^{\circ} \mathrm{C}$ due to formation of oxidation products. The weight gain is in decreasing sequence for MBD> LBD $>$ FBD. The isothermal TG graph in Figs. 3 and 4 shows that the weight gain due to formation of polymeric oxidation products are higher for BD samples with high percentage of polyunsaturated fatty acid ester content. The major fatty acid esters constituents of BD samples are given in Table (3). The foregoing discussion clearly shows that BD fuel of sunflower oil shows better oxidative stability in comparison to other tested oils with high percentage of unsaturated fatty acid content. The oxidative stability of BD fuel was further studied for the three $\mathrm{BD}$ samples $\left(\mathrm{FBDO}_{3}\right.$, $\mathrm{LBDO}_{3}, \mathrm{MBDO}_{3}$ ) after treatment with ozonated corresponding oil $1 \% \mathrm{wt}$. The oxygen content of biodiesel samples was increased by $14 \mathrm{wt} \%$ for $\mathrm{FBDO}_{3}$ and $\mathrm{LBDO}_{3}$ While a slight increase of $3 \mathrm{wt} \%$ only was shown for $\mathrm{MBDO}_{3}$. The higher oxygen content in biodiesel results in a more extensive chemical reaction and consequently less carbon residue is produced. The oxygen content of a fuel has a strong influence on its combustion properties (Sendzikiene et al., 2005). They stated that optimal oxygen content in diesel fuel mixture is $15-19 \%$ and the smoke index analysis showed that on increasing the fuel oxygen content the smoke index decrease considerably. Therefore, the burning of the biodiesel, which was produced through transesterification reaction followed by the mixing of ozonated corresponding oil $1 \%$ by weight showed higher combustion efficiency indicated by the high heat of enthalpy and therefore, promote the combustion characteristics and will reduce the emission of particulate matter.

The comparative study of the produced methyl esters $\mathrm{FBDO}_{3}, \mathrm{LBDO}_{3}$ and $\mathrm{MBDO}_{3}$ concluded that the higher heat content and better thermal properties DTG/ DTA over those FBD, LBD and MBD. This lower smoke opacity, lower exhaust temperatures and lower pour point. The number of unsaturated double carbon bonds of biodiesel when mixed with ozonated oil were reduced causing reduction of the combined oxidation rate. Thus, more oxygen by treatment with ozone, makes the combustion more complete and increased biodiesel stability at normal temperature. The data of GC indicated a methyl ester content is impurity free. The physico-chemical characteristics of biobiesel and biodiesel treated with ozonated oil have been determined to evaluate its capacity as modified fuel. These characteristics indicated the improvement of pour point especially for FBD and high flash point indicating higher degree of safety for fuel. Biodiesel treated with ozonated oil presents combustion heat in $\mathrm{J} / \mathrm{mg}$ seven folds compared with that produced by conventional diesel for $\mathrm{FBDO}_{3}$ and showed three folds greater for $\mathrm{LBDO}_{3}$. Although nearly the same heat was produced with $\mathrm{MBDO}_{3}$ compared to conventional diesel, the $\mathrm{MBDO}_{3}$ ' showed four folds heat greater compared to conventional diesel. Apparently, treatment with ozone modified biodiesel thermal properties and consequently modified its oxidation stability.

\section{ACKNOWLEDGMENTS}

The authors gratefully thank the US - Egypt Science and Technology Program; Joint Research Grant for financial support. A special thank to all the involved partners in this research for their fruitful co-operation (Institute of Petroleum Research and Cairo University).

\section{REFERENCES}

Ayhau, D., (2002).Biodiesel fuels from vegetable oils via catalytic and non-catalytic supercritical alcohol transesterification and other methods a survey. Ener. Conver. Manage., 44 (13), 2093- 2109.

Bailey, P. S., (1978). Ozonation in organic chemistry 1, olefinic compounds. Academic Press, New York.

Burno, L.; David, A.; Reckhow; D.; Brink, R., (1991). Ozone in water treatment application and engineering. Chapter II Second printing. Printed in USA. 54-57.

Buzas, J.; Simon and Hollo, J. (2005). Effect of the experimental conditions on the thermo oxidative behaviour of vegetable oil. J. Therm. Anal. Calorim., 12 (3), 397 - 405.

Cigizogu, K. B.; Ozaktas, T.; Karaosmanoglu, F., (1997). Used sunflower oil as an alternative fuel for diesel engines. Ener. Sour., 19 (6), $559-66$.

Canacki, M., (2007). The Potential of restaurant waste lipids as biodiesel feed stocks. Bioresour. Tech., 98 (1), 183 - 190.

Canac, M.; Gerpen, J. V., (2003). A pilot plant to produce biodiesel from high free fatty acid feedstocks. Trans. Am. Soc. Agric. Eng., 46 (4), 945 - 954.

Engelman, H. W.; Guenther D. A.; Silvis T. W., (1978). Vegetable oil as a diesel fuel. SAE Paper 78 DGP - 19.

Gerhard, K.; Kevin, R. S., (2005). Kinematic viscosity of biodiesel fuel components and related compounds. Influence of compound structure and comparison to petrodiesel fuel components. Fuel, 84 (9), 1059-1065.

Gerhard, K., (2001). Analytical methods used in the production and fuel quality assessment of biodiesel. Transactions of the ASAE., 44(2), 193 - 200.

Glaze, W. H.; (1988). Summary: Workshop on By-products of ozonation. AWWA Research Foundation, Denver, CO. 
Granados, M. L.; Poves, N. D. Z.; Alonso, D. M.; Mariscal, R.; Galisteo, F. C.; Tost, R. M., (2007). Biodiesel from sunflower oil using activated calcium oxide. Appl Catal B: Environ., 73 (3-4), 317 - 326.

Hoigne, J.; Bader, H., (1983b). Rate constant reaction of ozone with organic and Inorganic compounds in water. II. Dissociating Organic Compounds. Water Res., 17 (2), 185 194.

Jayadas, N. H.; Prabhakaran, K. N., (2006).Coconut oil as base oil for industrial lubricants - evaluation and modification of thermal, oxidative and low temperature properties. Tribio. Int., 39 (9), $873-878$.

Jon Van, G., (2005). Biodiesel processing and production. Fuel Proc. Tech., 86 (10), 1097 - 1107.

Langue, C. M.; Lo, K. V.; Staley, L. M., (1988). Waste vegetable oil as a diesel fuel extender. Canadian Agri. Eng., 30 (1), 27 32.

Leung, D. Y. C.; Guo, Y., (2006). Transesterification of net and used frying oil: Optimization for biodiesel production. Fuel Proc. Tech., 87 (1), $883-890$.

Marta, M.; ConceiCao; Rober Lucia, A.; Canderia; Fernando, C. Silva; Aline, F. Bezerra; Valter, J. Fernandes Jr.; Antonio. G. Souza (2007). Thermo analytical characterization of castor oil biodiesel. Renew. Sustain. Ener. Rev., 11 (5), 964975.

Martin, M., (1996). Diesel fuel derived from vegetable oils, VI: Specifications and quality control of biodiesel. Bioresou. Tech., 56 (1), 7 -11.

Nestor, U.; Soriano, Jr.; Veronica, P.; Migo; Masatoshi, N., (2006). Ozonated vegetable oil as pour point depressant for neat biodiesel. Fuel, 85 (1), 25-31.

Ozbay, N.; Oktar, N.; Tapan, N. A., (2008). Esterification of free fatty acids in waste cooking oils (WCO): role of ion exchange resins. Fuel. doi:10, 101/j. Fuel, 12.010.

Ramadhas, A. S.; Jayaraj, S.; Muraleedharam, C., (2005). Biodiesel production from high FFA rubber seed oil. Fuel, 84 (4), $335-340$.
Refaat, A. A. ; Attia, N. K.; Sibak, H. A.; El Sheltaway, S. T.; El Diwani, G. I., (2008). Production optimization and quality assessment of biodiesel from waste vegetable oil. Int. J. Environ. Sci. Tech., 5 (1), 75 -82.

Sarin, R.; Sharma, M.; Sinharay, S.; Malhotra, R. K., (2007). Jatropha-palm biodiesel blends: an optimum mix for Asia. Fuel, 86 (1), 1365 - 1371.

Schaleekamp, M., (1978). Experience with ozone in Switzerland with special respect to the changes in hygienically questionable materials. In Water Berlin 1977, edited by O.H.Hess, P.31. Also given in ozoneus, May 1978, International Ozone Association.

Sendzikiene, E.; Makareviciene, V.; Janulis, P., (2005). Influence of oxygen content on diesel engine exhaust emissions. Renew. Ener., 31 (15), 2505 - 2512.

Sharma, Y. C.; Singh, B., (2007). Development of biodiesel from Karanja, a tree found in rural India. Fuel. doi:10.1016/ J. Fuel, 08.001.

Spanggord and Mc Ciurg (1978). Ozone methods and ozone chemistry of selected organics in water. In basic chemistry. in ozone/chlorine dioxide oxidation products of organic materials. Edited by R. C. Rice and J. A. contruvo, IOA, Cleveland, Ohio.

Tashtoush, G. M.; Al Widyan, M. I.; Al Shyouckh, A. O. (2004). Experimental Study on evaluation and optimization of conversion of waste animal fat into biodiesel. Energ. Consev. Manage., 45 (17), 2697-2711.

Wang, Y.; Ou, S.; Liu, P.; Zhang, Z., (2007). Preparation of biodiesel from waste cooking oil via two - step catalyzed process. Energy Conser. Manage., 48 (1), 184-188.

Zhang, Y.; Dabe‘, M. A.; Mclean, D. D. I., (2003). Biodiesel production from waste cooking oil: 1 . Process design and technological assessment. Bioresour. Tech., 89 (1), 1-16.

\title{
AUTHOR (S) BIOSKETCHES
}

EI Diwani, G., Ph.D., Professor, Chemical Engineering and Pilot Plant Department, National Research Center, Cairo, Egypt. Email: geldiwani@yahoo.com

El Rafie, Sh., Ph.D., Assistant professor, Chemical Engineering and Pilot Plant Department, National Research Center, Cairo, Egypt. Email: shelrafie0000@yahoo.com

\author{
This article should be referenced as follows: \\ El Diwani, G.; El Rafie, Sh., (2008). Modification of thermal and oxidative properties of biodiesel produced from \\ vegetable oils. Int. J. Environ. Sci. Tech., 5 (3), 391-400.
}

